\title{
A Ergonomia no comércio da carne: análise ergonômica do único açougue público de uma cidade do interior do nordeste brasileiro
}

\author{
Ergonomics and the meat trade: ergonomic analysis of the only public \\ butcher shop in a city in the northeast of Brazil
}

TERCILIA MENDONÇA

Graduanda, Universidade Federal de Pernambuco, tercilia-23@hotmail.com

BRUNO BARROS

Mestre, Universidade Federal de Pernambuco, barros_bruno@hotmail.com

\section{RESUMO}

Caracterizada por uma atividade de origem mais artesanal, o trabalho em açougues públicos comumente envolve esforço braçal para a manipulação e transporte de carnes, onde a manipulação na desossa e nos cortes torna-o um trabalho exaustivo. Para que possa atender para às normas de vigilância sanitária, bem como aos diversos tipos de usuários que normalmente frequentam o local, açougues públicos demandam aspectos como amplitude do espaço, circulação adequada, açougueiros trajados conforme as regras de saúde pública, a obrigatoriedade de as carnes estarem refrigeradas até a hora do ato da compra, tal qual especificações para todos os equipamentos os quais entrarão em contato com a carne. Dentro deste contexto, a corrente pesquisa repousou o foco na análise ergonômica do único açougue público de uma cidade do interior do nordeste brasileiro. Para a condução da investigação, guiamo-nos pela Metodologia para Projetos de Construção Centrados no Usuário, proposta por Attaianese e Duca (2012), através da qual foram apresentados o Briefing de Design, Perfis de Usuários e Grupos de Ajuste, Análise da Tarefa e Adaptação às Necessidades dos Usuários. A investigação revelou diversas inadequações de caráter consideravelmente relevante e, a partir de então, foi possível estabelecer uma série de recomendações ergonômicas para adequação do espaço.

PALAVRAS-CHAVE: Ergonomia do ambiente construído; análise ergonômica; açougue público.

\section{ABSTRACT}

Expressed by an activity of a more artisanal origin, work in common public agencies involves the manual effort for handling and transporting meat, where handling in boning and cutting becomes an exhausting task. For those who can meet sanitary standards, as well as for various types of users who are usually local or public, they require public aspects such as the spaciousness of the space, adequate 


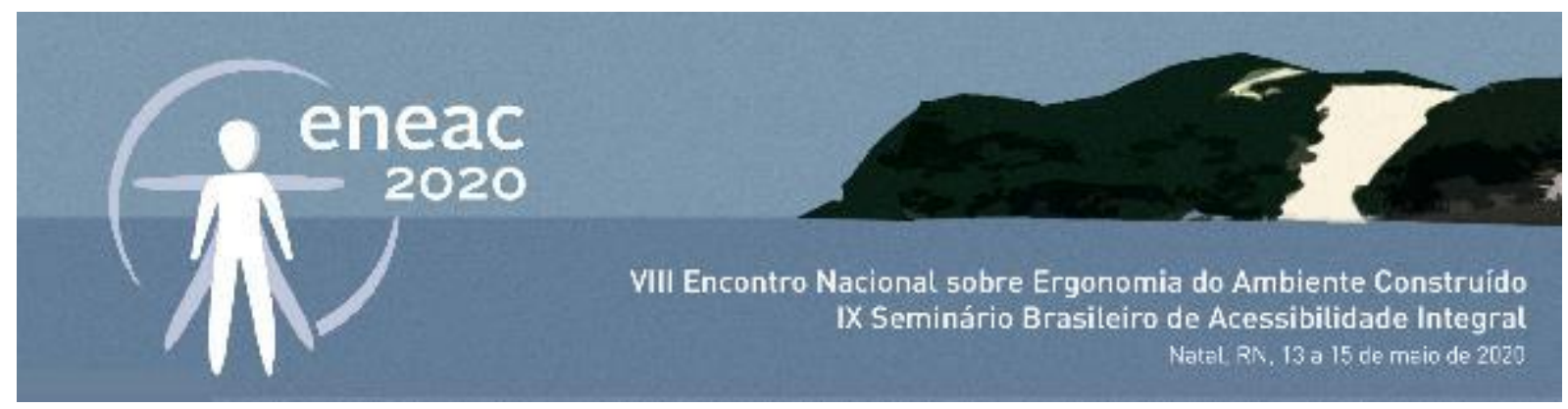

circulation, butchers designed according to public health rules, an obligation for meat to be refrigerated until one hour from the time of purchase, such as specifications for all equipment or which items come into contact with a meat. Within this context, current research reviews or focuses on the ergonomic analysis of the only public butcher shop in a city in the interior of northeastern Brazil. To conduct the investigation, Methodology for User-Centered Construction Projects, proposed by Attaianese and Duca (2012), execution of which were presented the Design Briefing, User Profiles and Adjustment Groups, Task Analysis and Adaptation to Needs Users. The investigation revealed several inadequacies of a relevant nature and, from then on, it was possible to establish a series of ergonomic recommendations for space adequacy.

KEYWORDS: built environment ergonomics; ergonomic analysis; public butcher

\section{INTRODUÇÃO}

O Brasil, como um dos maiores exportadores mundiais de carnes bovina e de frango do mundo, fornece cerca de $20 \%$ das exportações globais totais de bovinos, segundo o Departamento de Agricultura dos Estados Unidos (USDA). De acordo com a pesquisa realizada pela OCDE (Organização para cooperação e Desenvolvimento Econômico), o consumo de carne por pessoa no Brasil, tende a subir $20 \%$ até o ano de 2021, o que representa em quantidade um aumento de $0,96 \mathrm{~kg}$ para $1,5 \mathrm{~kg}$. Uma vez que esse mercado de carne ainda cresce, faz-se relevante voltar o olhar ergonômico sobre os sistemas de trabalho que o envolvem, no sentido de verificar inadequações e propor recomendações que visem a qualidade de vida no desempenho das atividades em estabelecimentos de comercialização pública da carne.

De acordo com Sarmento e Villarouco (2018), a relação de troca existente entre a pessoa e o meio físico vivenciado é bilateral, havendo mútua influência, o ambiente atua sobre a pessoa, que por sua vez, age sobre os fatores espaciais que o determinam. Por isso o ambiente deve ser planejado para oferecer plenas condições funcionais e saudáveis, e de satisfação para seus usuários, diretos ou indiretos.

Se tratando de um Açougue Público, a enorme quantidade de usuários indiretos que o mesmo recebe diariamente, e as condições que seus usuários diretos podem estar expostos revela a importância desses locais estarem em frequente análise e fiscalização dos órgãos responsáveis. Uma vez que, os açougueiros, entregadores da carne e os compradores, estão sujeitos a adquirir tanto doenças osteomusculares com as atividades repetitivas, quanto suscetíveis a agentes patogênicos, que podem causar desde infecções até a morte.

Portanto, a presente pesquisa estabeleceu uma análise do único açougue público de uma cidade do interior do nordeste brasileiro, a qual possui pouco mais de duzentos mil habitantes. $O$ intuito foi o de, através dos resultados obtidos, fornecer para o design, recomendações ergonômicas que possam ser levadas em consideração para adaptações e/ou projetos de açougues públicos e, até mesmo, açougues de empresas privadas. Para tanto, lançou-se mão da Metodologia para Projetos de Construção Centrados no Usuário, proposta por Attaianese e Duca (2012), a qual conduziu o estudo ao alcance das resoluções. 


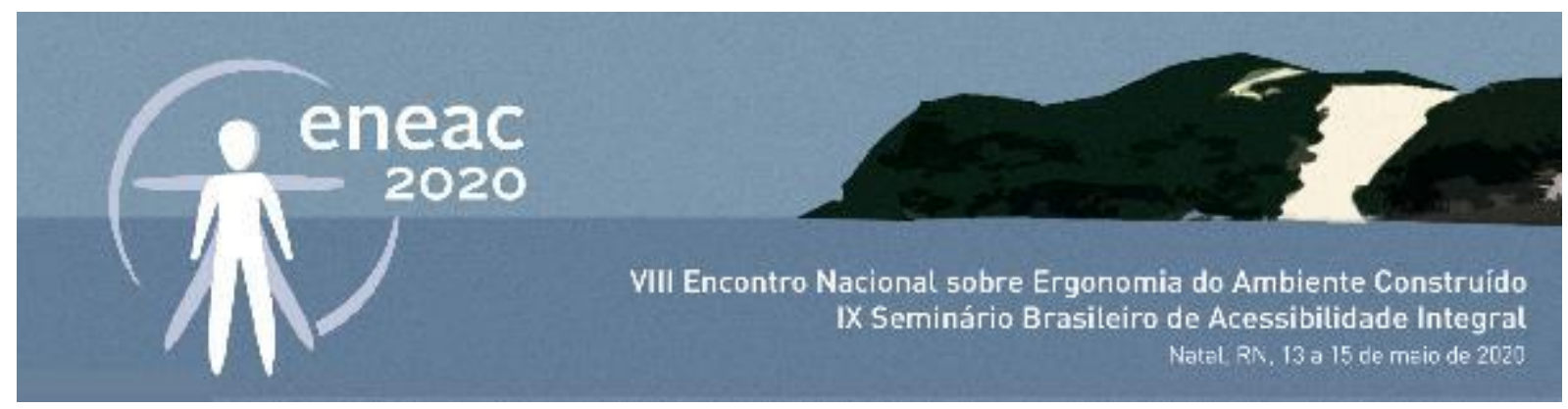

\section{FUNDAMENTAÇÃO TEÓRICA}

A Classificação Brasileira de Ocupações (CBO) descreve os açougueiros como profissionais que "abatem bovinos e aves controlando a temperatura e velocidade de máquinas. Preparam carcaças de animais (aves, bovinos, caprinos, ovinos e suínos) limpando, retirando vísceras, depilando, escaldando, riscando pequenos cortes e separando cabeças e carcaças para análises laboratoriais" (CBO, $2013 \mathrm{~s} / \mathrm{p})$. Em adição à caracterização, o documento ainda destaca que estes profissionais também "preparam carnes para comercialização, desossando, identificando tipos, marcando, fatiando, pesando e cortando. Realizam tratamentos especiais em carnes, salgando, secando, prensando e adicionando conservantes" (CBO, $2013 \mathrm{~s} / \mathrm{p}$ ). Com relação à organização da atividade, a CBO descreve que estes "acondicionam carnes em embalagens individuais, manualmente ou com o auxílio de máquinas de embalagem a vácuo. Trabalham em conformidade a normas e procedimentos técnicos e de qualidade, segurança, higiene, saúde e preservação ambiental” (CBO, $2013 \mathrm{~s} / \mathrm{p}$ ).

De acordo com a norma técnica da secretária de saúde de Pernambuco - SESAU de № 1, publicado no DOM em Recife no dia um de junho de 2017, no artigo 99o, inciso segundo, alínea B, as carnes precisam estar refrigeradas a uma temperatura entre quatro e sete graus Celsius ou conforme recomendação produtor, expresso na embalagem dos produtos. Entretanto, neste sentido, Tondo $(2017 \mathrm{~s} / \mathrm{p})$ ressalta que "o consumidor não percebe facilmente quando a carne está podre. Os casos de surto de doenças transmitidas por alimentos, como Salmonelose e outras, sempre ocorrem com a carne visualmente e sensorialmente perfeita". Por esse motivo, Cymbaluk (2017) alerta que é fundamental o controle de qualidade na indústria alimentícia e a fiscalização rígida, uma vez que comer carne estragada pode causar dor de cabeça, vômitos, diarreia, febre e até mesmo levar à morte. O autor complementa afirmando que a carne pode estragar mesmo se estiver em um ambiente higienizado, pois são as próprias bactérias presentes que começam a se multiplicar. Dentro deste contexto Tondo (2017) é enfático ao destacar que "a carne de muito boa qualidade tem coliformes fecais, isso é normal, mas em níveis baixos, se deixar em temperatura ambiente, aquele pouquinho vai crescer bastante."

De acordo com o decreto 38691 de 10/03/1997, atualizado em 19/12/2011, que trata a respeito do regulamento da inspeção e fiscalização sanitária dos produtos de origem animal, consta no Art. 39o as normas para a aprovação do determinado estabelecimento. Devido à grande quantidade de incisos constados no Art. 390, foram citados apenas alguns dos incisos que regem as condições que o ambiente deve atender:

I - localizar-se em ponto distante de fonte produtora de odores indesejáveis, de qualquer natureza; II - ser instalada, de preferência, em centro de terreno cercado, afastado dos limites das vias públicas no mínimo cinco $[. .$.

III - dispor de luz natural e artificial e ventilação suficientes, em todas as dependências, respeitadas as peculiaridades de ordem tecnológica cabíveis;

IV - possuir piso de material impermeável, resistente à abrasão e à corrosão, ligeiramente inclinado, construído de modo a facilitar a colheita e o escoamento de águas residuais e permitir sua boa limpeza e higienização;

$\mathrm{V}$ - ter paredes lisas, impermeabilizadas com material de cor clara, aprovado pelo IMA, numa altura de pelo menos dois (2) metros, de fácil lavagem e higienização, com ângulos e cantos arredondados; $\mathrm{VI}$ - possuir, nas dependências de elaboração de comestíveis, forro de material resistente à umidade e vapores, construído de modo a evitar o acúmulo de sujeira e a contaminação, de fácil limpeza e 


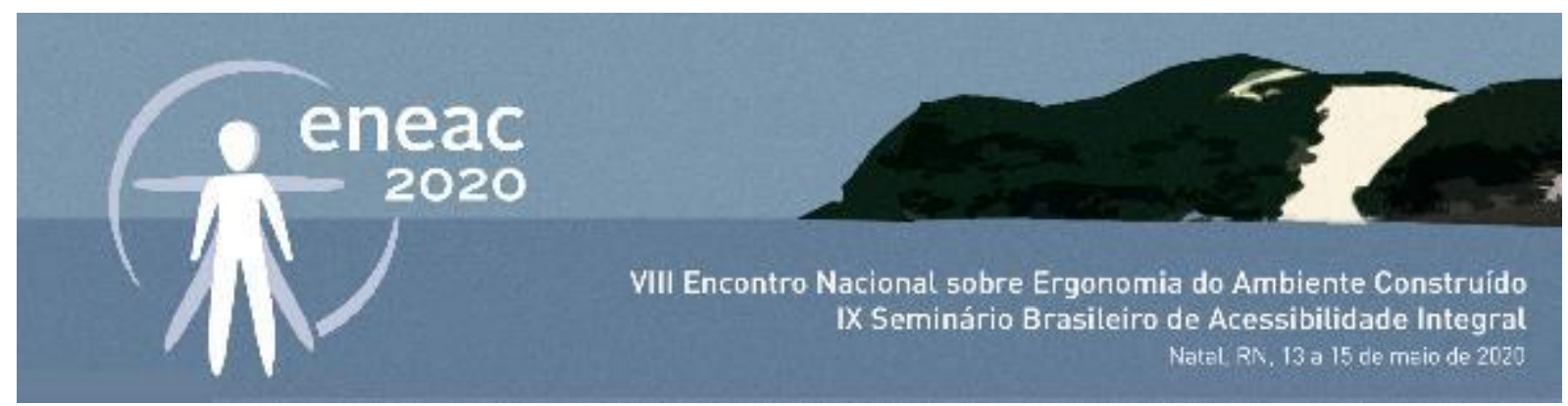

\begin{abstract}
higienização, vedado o uso de madeira, podendo ele ser dispensado no caso em que a cobertura proporcione perfeita vedação à entrada de poeira, insetos e pássaros, e assegure fácil higienização; VII - dispor de dependências e instalações mínimas segundo definição do IMA, respeitadas as finalidades a que se destine, para recepção, industrialização, embalagem, depósito e expedição de produto comestível, sempre separadas, por meio de paredes totais, das destinadas ao preparo de produto não comestivel;

VIII - dispor de dependências para administração, oficina e depósitos diversos, separadas do corpo industrial sempre que recomendado pelo IMA;

IX - estar equipado com mesas revestidas de material impermeável, aprovado pelo IMA, para os trabalhos de manipulação e preparo de matéria-prima e produto comestível, dispostas ou construídas de forma a permitir fácil higienização (Artigo $39^{\circ}$ do decreto 38691 de 10/03/1997).
\end{abstract}

A agência nacional de vigilância sanitária - ANIVISA, no item 4.1.17 da Resolução-RDC 216/2004, que dispõe sobre as Boas Práticas para Serviços de Alimentação, determina que:

[...] as superfícies dos utensílios utilizados na preparação de alimentos devem ser lisas, impermeáveis, laváveis e estar isentas de rugosidades, frestas e outras imperfeições que possam comprometer a higienização dos mesmos e serem fontes de contaminação dos alimentos. Esclarecemos que a madeira não atende a todos esses requisitos (ANVISA - Resolução-RDC 216/2004, item 4.1.17, 2004).

No setor de açougue, estudos epidemiológicos identificaram casos de DORT em ocupações de profissionais açougueiros (MELZER, 2008). O autor afirma que, em se tratando de estabelecimentos de açougue, entre os aspectos mais perigosos destacam-se a utilização de ferramentas (facas), ganchos pontiagudos e máquinas cortantes. Vasconcellos; Pignatti e Pignati (2009) realizaram um estudo em frigoríficos do Mato Grosso, o qual identificou que os acidentes mais comuns possuem como agente causador a faca, sendo os membros superiores as partes do corpo mais atingidas.

\title{
3 METODOLOGIA
}

Para o seguimento do estudo, foi utilizada a Metodologia para Projetos de Construção Centrados no Usuário, proposta por Attaianese e Duca (2012). Segundo Sarmento e Villarouco (2018), esta metodologia envolve sobretudo os usuários e utiliza a norma internacional ISO 13407/1999, que determina o design de sistemas centrado nos usuários, com clareza da caracterização dos usuários e de todas as tarefas que implicam no funcionamento do sistema de atividades. A metodologia segue uma sequência de sete etapas: 1) Briefing de Design; 2) Perfis de Usuários e Grupos de Ajuste; 3) Análise da Tarefa; 4) Adaptação às Necessidades dos Usuários; 5) Primeiros Detalhes Arquitetônicos; 6) Validação das Soluções de Design; 7) Avaliação da Edificação em Uso. Entretanto, as etapas 5, 6 e 7 não foram adotadas na referente pesquisa, uma vez que os objetivos deste trabalho se baseiam apenas na proposição de recomendações generalizadas para ambientes similares.

Dentre as etapas contempladas neste estudo, a etapa de Briefing de Design buscou reunir informações sobre os requisitos necessários ao ambiente para satisfazer as demandas dos usuários e, para isso, pode se utilizar de algumas ferramentas de coleta de dados como entrevistas e questionários. A partir da realização de investigação se tornou possível constatar os Perfis de Usuários e Grupos de Ajuste envolvidos, estes se dividem entre diretos e indiretos, sendo os usuários diretos o principal a executar as atividades e o que executa a ação frequentemente; por outro lado, também foram consideradas informações acerca dos usuários indiretos, que estão envolvidos com o ambiente e eventualmente executam algumas atividades. 


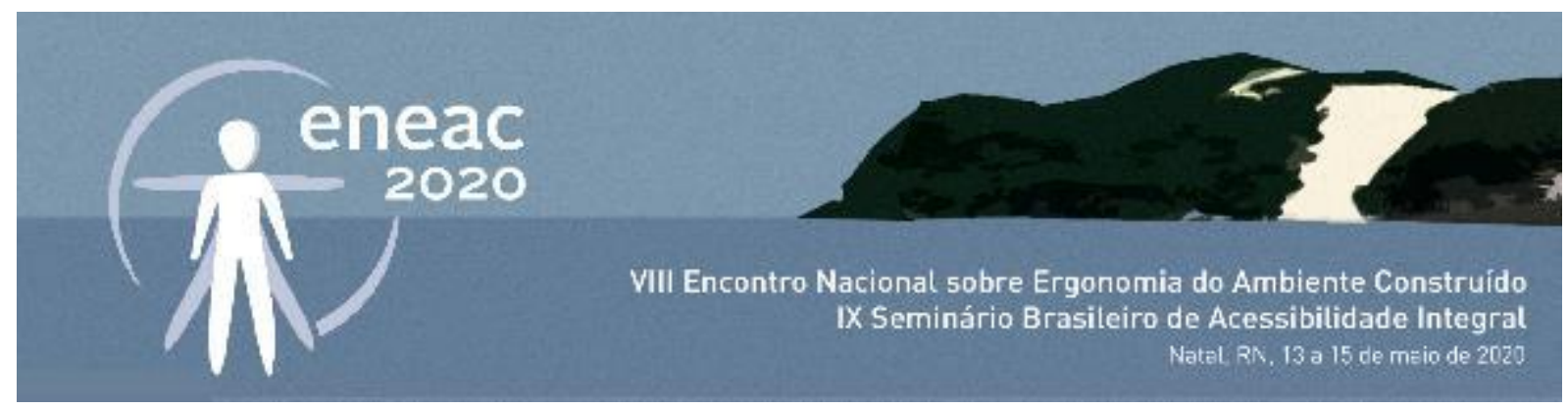

A Análise da Tarefa, terceira etapa metodológica, destinou-se a descrever as observações sistemáticas e assistemáticas, e identificar as atividades realizadas no ambiente pelo usuário em foco, sendo verificados os objetivos que se pretende atingir, quais os requisitos necessários, de que meios o usuário se utiliza, posturas assumidas na realização das tarefas, condições e constrangimentos do ambiente, também fazendo aferições de conforto ambiental.

A etapa de Adaptação às Necessidades dos Usuários, última etapa utilizada neste artigo, é caracterizada pela da síntese de dados, nesta fase foram apontados os problemas possivelmente encontrados, assimilando as adaptações necessárias ao projeto, contemplando as correções apontadas, para que pudessem ser feitas as recomendações ergonômicas do ambiente para o projeto centrado no ser humano.

Como referência nas avaliações, nessa pesquisa, foram utilizadas as normas de regulamentação do município, em conjunto com normas nacionais, buscando dessa maneira adequar da melhor forma possível a amplitude de um açougue público, visando sempre o bem-estar do ser humano.

\section{RESULTADOS}

\section{Briefing}

Na maioria dos supermercados de grande porte existe o setor do açougue, onde a carne é exibida em uma vitrine refrigerada e um açougueiro devidamente treinado, usando trajes específicos, tem a função de pegar, cortar e pesar a carne escolhida pelo cliente. Por se tratar de um estabelecimento particular a normas de saúde pública tendem a ser seguidas com maior rigor, enquanto em um açougue público é de costume burlar algumas regras, já que o mesmo é dividido em vários módulos e em cada um deles trabalha um açougueiro diferente, de um modo distinto e por isso fica mais difícil controlar e supervisionar a forma que cada um trabalha.

O açougue selecionado para análise, por essência, é caracterizado por ser um estabelecimento comercial que vende carne fresca. Sob um aspecto físico estrutural geral, é ideal averiguar se este tipo de estabelecimento, para atender os diversos tipos de usuários, oferece aspectos como amplitude no espaço e circulação adequada, assim como açougueiros trajados conforme as regras de saúde pública, como o uso de toucas e luvas. Também é importante investigar se as carnes permanecem refrigeradas até a hora da compra e se o balcão é de inox, ou revestido com placa de altileno (material plástico desenvolvido para evitar contaminação microbiológica), já que é lavável e não poroso. Se faz necessário, ainda, verificar se esse ambiente necessita ou pode faz uso de equipamentos, como a serra de fita para cortar carnes congeladas ou com ossos; gancheira, para pendurar carne; picador de carne; amaciador de carne; utensílios para corte e desossa de carne (facas); luva de aço para proteção; balanças eletrônicas com etiquetadores e outros componentes de acordo com a quantidade e tipo de carne que cada açougueiro trabalha. Outro fator importante a ser observado são os pisos e os demais revestimentos, os quais precisam estar de acordo com normas da vigilância sanitária.

No açougue público selecionado para estudo um fator importante a ser observado é que o acesso ao ambiente interno é livre para todos (figura 01), não havendo fiscalização, isso inclui a presença de alguns animais. 

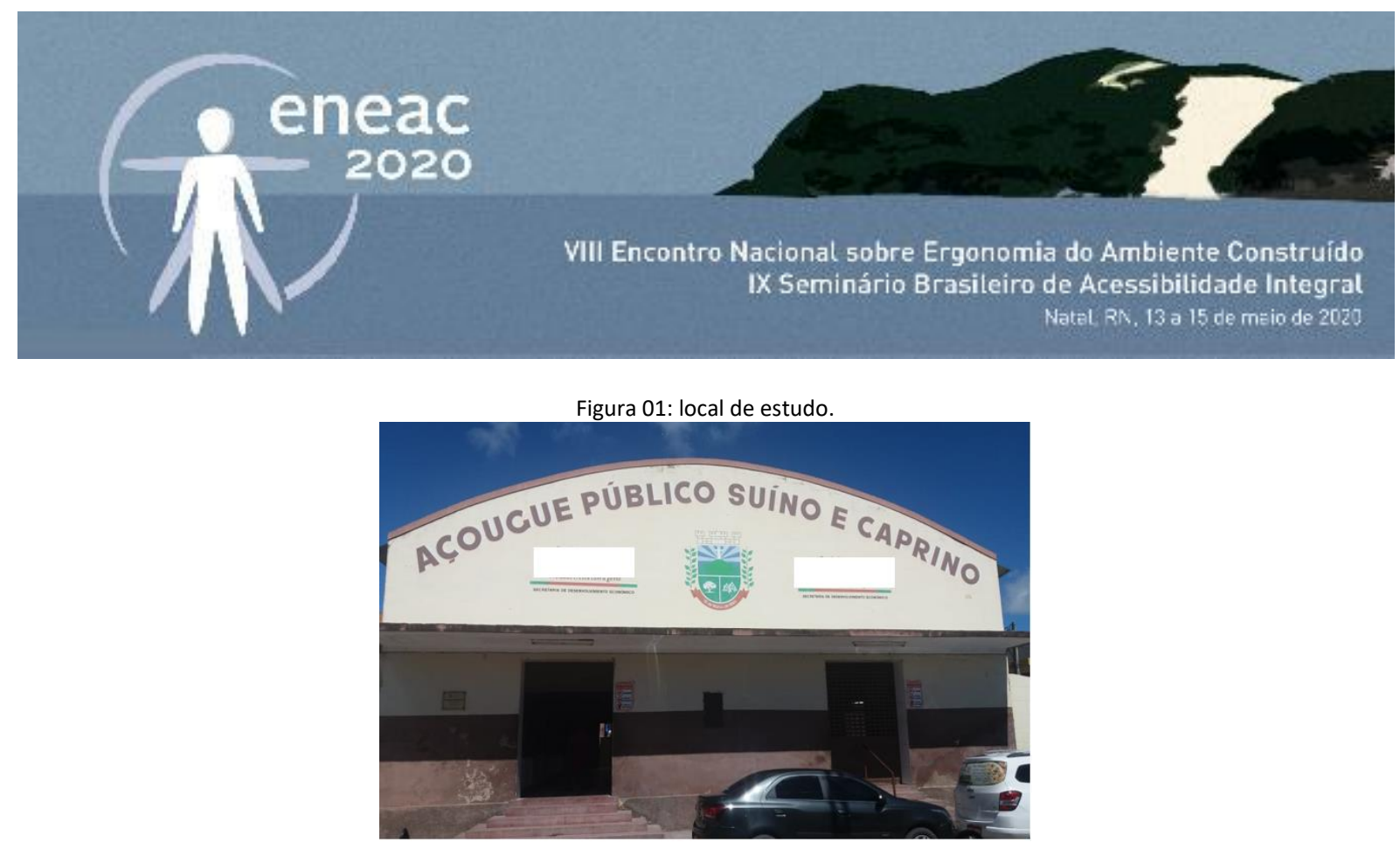

Fonte: capturado pelos autores para a pesquisa (2020).

Outra demanda inicial refere-se à necessidade de uma maior atenção às bancadas de trabalho e partes gerais da sua estrutura de alvenaria, boa parte se encontra quebrada, rachada, ou simplesmente carece de uma limpeza adequada.

\section{Perfis de Usuários e Grupos de Ajuste}

Os usuários diretos nesse estudo, os açougueiros, são na maioria homens com idade entre 35 e 60 anos, sendo o mais velho dos usuários um homem com 70 anos. Os usuários trabalham de domingo a sábado nesse local, normalmente das seis da manhã até as quatro da tarde, nos dias de maior movimento (como os sábados e as vezes os domingos) alguns açougueiros chegam as três horas da manhã e largam as cinco da tarde, ficando no lugar por até 14 horas, muitas vezes fazendo suas refeições dentro do espaço.

Como usuários indiretos tem-se os clientes, homens e mulheres tanto adultos como idosos que vão ao espaço comprar os diversos tipos de carne, também fazem parte dos usuários indiretos os entregadores de carne, que constantemente frequentam o local levando a mercadoria.

\section{Análise da Tarefa}

Essa fase possibilitou uma análise mais aprofundada do ambiente durante a sua utilização pelos diversos tipos de usuários que são parte desse estudo de caso, assim tornou-se mais simples a compreensão de como está sendo realizada as atividades cotidianas dos usuários no açougue.

Foi possível observar também os riscos de possíveis infecções por germes e bactérias, bem como os possíveis riscos de acidentes físicos que podem vir a ser causados por causa de posturas nocivas assumidas pelos usuários durante a execução de suas atividades, além disso, ao observar o usuário realizando as posições que assume durante o exercício dos seus afazeres, surgem alguns pensamentos a respeito de estratégias que poderão serem exploradas como soluções projetuais, de modo que venham a facilitar a vida dos diversos usuários que trabalham no açougue e ainda resolver, ou pelo menos amenizar, as inadequações presentes no ambiente que estão dificultando a realização dessas atividades e gerando riscos à saúde humana.

Também foram verificadas nesta fase (em adição à metodologia) aspectos de conforto ambiental, como os índices de iluminação, ruído e temperatura do ambiente, para em seguida compara-los com os níveis propostos pela ABNT. 


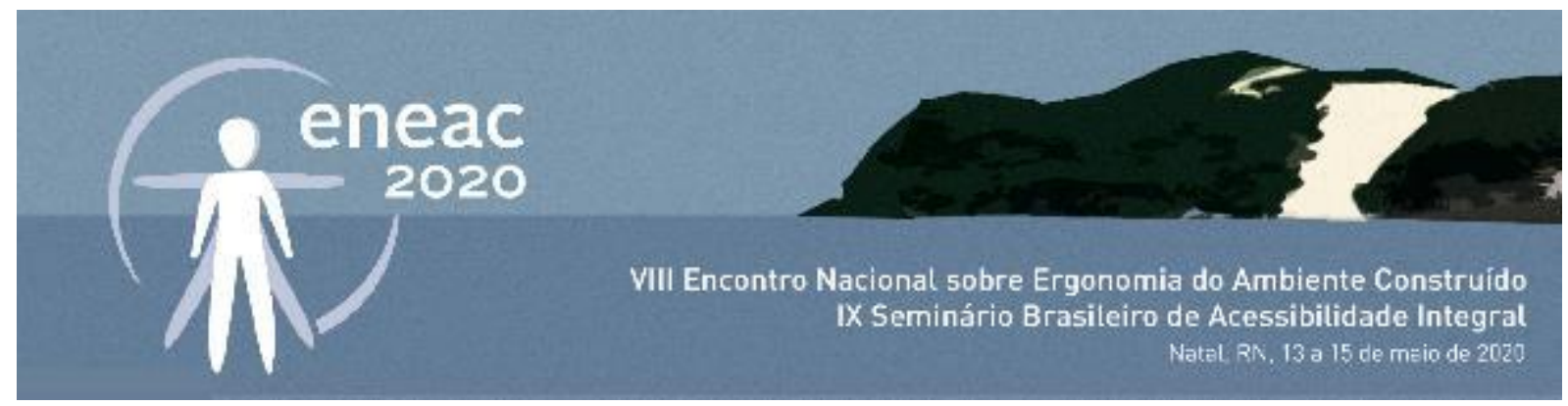

\section{Fixação e retirada das carnes}

Todos os dias, no início e no fim do expediente, os açougueiros executam a atividade de pendurar as carnes e as retira-las do varal de aço inox, os pedaços pendurados vão desde pequenas partes cortadas ou peças inteiras de um animal que chega a passar de $50 \mathrm{~kg}$. Além dos horários específicos para essa atividade, durante o horário de trabalho, estes funcionários também têm que retira-las e pendura-las diversas vezes a pedidos dos consumidores. O membro superior estendido e elevado acima do nível do ombro, principalmente quando o usuário soma essa posição ao fato de estar segurando alguma carga pesada, promove o risco de lesões osteomusculares, dores e vários desconfortos (Figura 02, A e B).

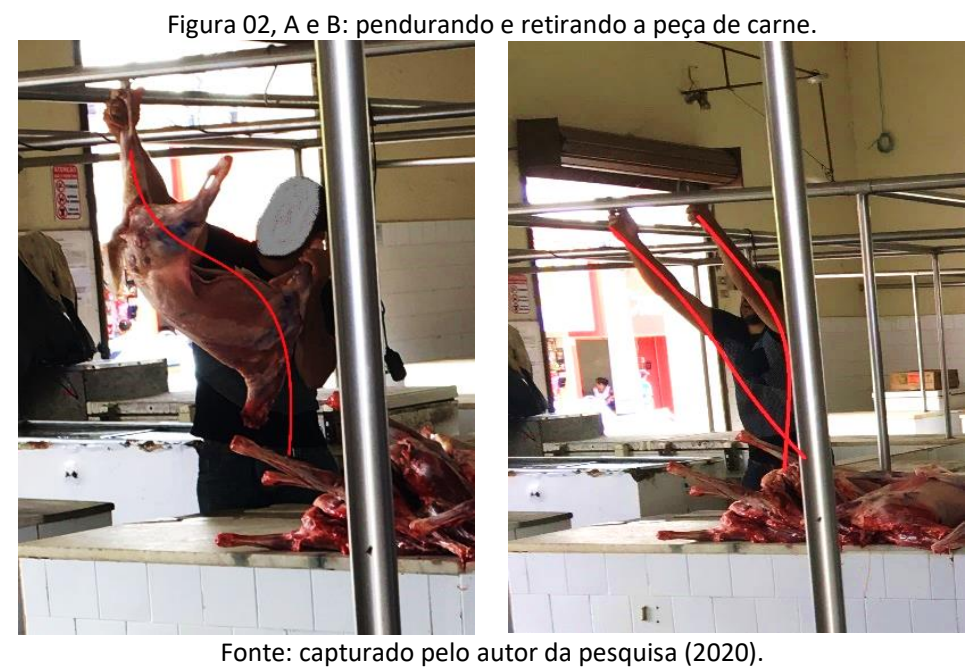

\section{Corte de carne na máquina elétrica e corte de carne com uso da faca}

Quando se faz necessário, o açougueiro faz uso de máquinas elétricas de cortes, contudo, a bancada não é posicionada em altura antropometricamente adequada para os usuários em questão, o pescoço do usuário fica flexionado a mais de $30^{\circ}$ (Figura 03, A). Além disto, seus ombros também se elevam, essas duas posturas promovem o surgimento de dores e desconforto no pescoço, ombros e coluna cervical, podendo vir a gerar lesões graves a longos prazo, como hérnias e bursite.

Quando os clientes pedem para fazer cortes simples e rápidos como a retirada do excesso de gordura das carnes, ou fatiar a carne de um modo específico, é utilizada apenas a faca. Neste sentido, o fato das bancadas terem uma altura padronizada de apenas $60 \mathrm{~cm}$ força os usuários a assumirem uma postura inadequada de tronco e pescoço, o que se agrava ao ter que repetir essa atividade várias vezes ao dia (Figura 03, B e C). O tronco e o pescoço acentuadamente flexionados e os movimentos repetitivos dos membros superiores, somados ao fato dos açougueiros estarem de pé durante a atividade, pode promover o surgimento de fadigas musculares, sobrecarga e dores na lombar, ombros, pescoço e membros inferiores, bem como inchaços e dificuldade de circulação sanguínea em pernas e pés. 

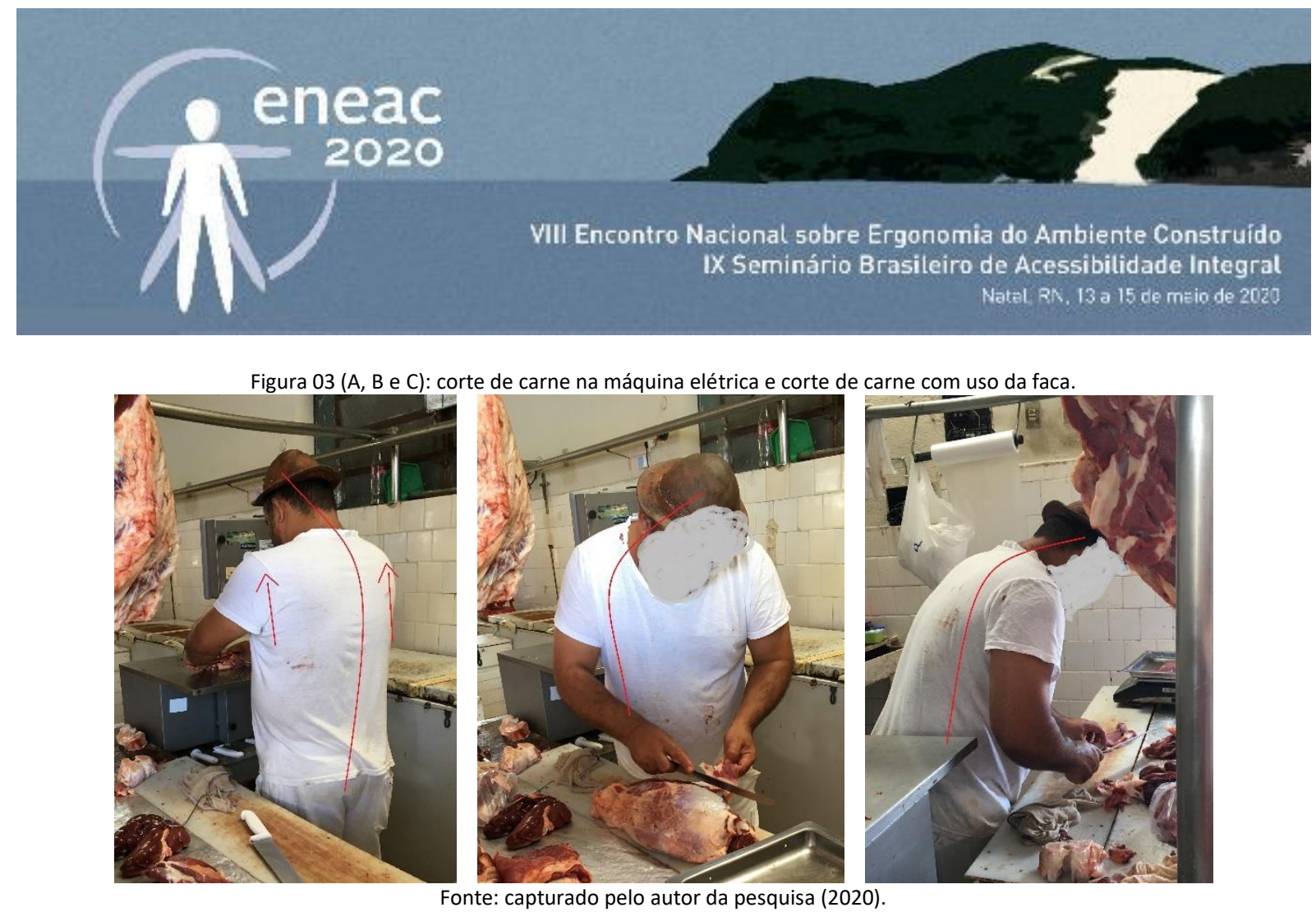

Ainda é importante destacar diversos riscos os quais os usuários diretos e indiretos estão expostos, tais como a incidência de acidentes ou lesões, não só apenas pelas posturas assumidas durante as atividades, mas problemas como possíveis intoxicações alimentares, tendo em vista a forma de armazenamento da carne.

Tanto para os seus usuários diretos, quanto para aqueles que fazem uso do espaço eventualmente, é necessária uma readequação da estrutura e materiais, como a possibilidade de um treinamento para todos os açougueiros. Foi possível observar balcões quebrados, peças de cerâmica faltando ou rachadas, carnes expostas sem nenhum tipo de proteção ou refrigeração, açougueiros que não usam trajes específicos (podendo contaminar ainda mais as carnes, ou sofrer lesões na utilização das facas, moedores e máquinas de corte). Neste ponto, também percebemos que o cliente está exposto a agentes de risco dentro do açougue, assim como os açougueiros que sofrem com a falta de manutenção nos revestimentos do local.

A análise do espaço também revelou inadequações físicas no ambiente. Durante as observações (reforçadas por entrevistas realizadas com os usuários diretos e indiretos do local), foi percebido que durante o horário comercial a maior parte das carnes ficam expostas sem nenhum tipo de proteção por até 10 horas (Figura 04), essa foi a questão de maior importância e risco, analisada no ambiente.

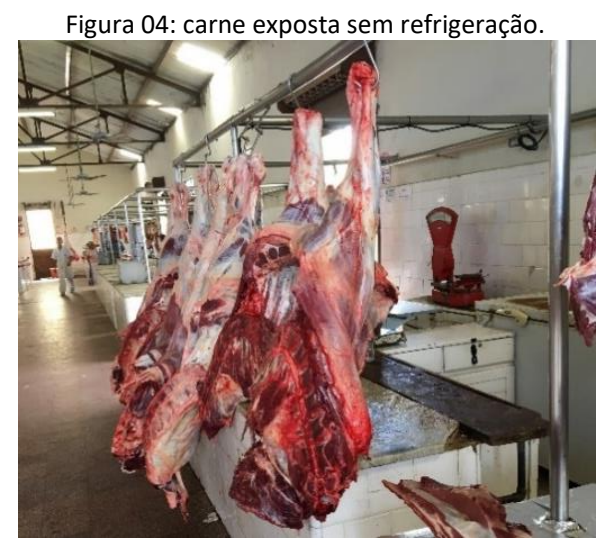

Fonte: capturado pelo autor da pesquisa (2020). 


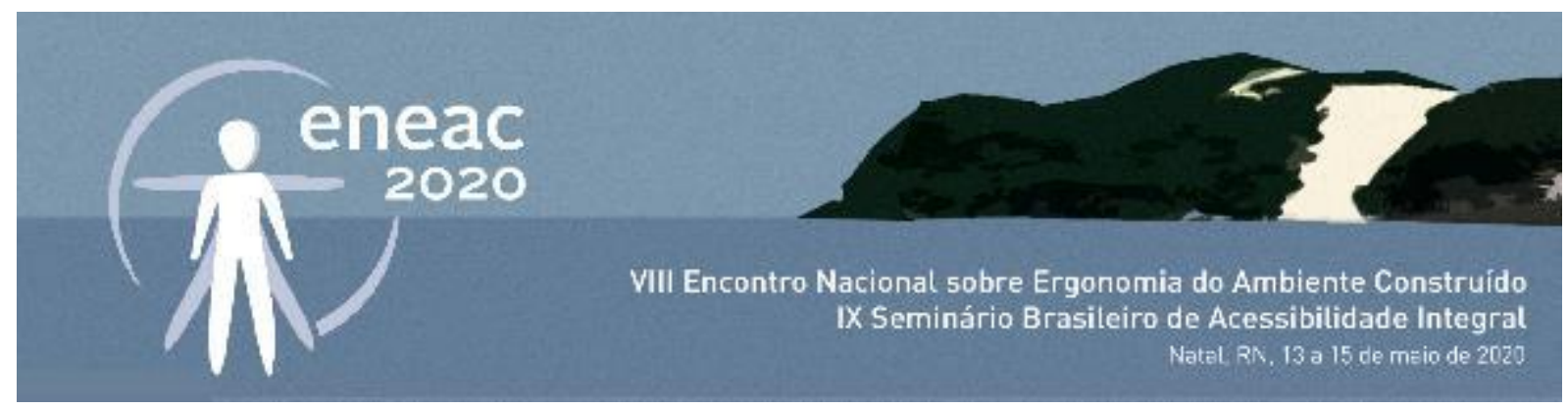

Durante as análises realizadas no ambiente foi visto que boa parte dos açougueiros tentaram ampliar o espaço da bancada, colocando uma espécie de paliativo feito a partir de tábuas de madeira sem tratamento algum na superfície, as madeiras sem impermeabilização tendem a infiltrar água e resíduos mais rápido, proliferando fungos e germes entre os frisos da madeira (Figura 5, A).

As bancadas que fazem parte da estrutura original são todas de mármore, e por ser um material poroso é mais suscetível a manchas e pode absorver gordura, assim como também não suportam os impactos que os açougueiros fazem com o uso de martelos para desossar as carnes. Em função disso a qualidade e manutenção das bancadas está degradada, a maioria se encontra quebrada, rachada e desgastada, o que contribui no acúmulo de germes e bactérias (figura 05, B). Na tentativa os poros e frisos presente na bancada de mármore, alguns açougueiros cobrem o balcão com folha de papel alumínio (Figura 05, C), o que só serve como proteção de imediato, visto que ao passar a faca o papel alumínio irá se rasgar, e até mesmo apenas com o manuseio da carne a folha tende a romper, correndo risco de o cliente levar para casa pedaços de carne com resíduos do alumínio.

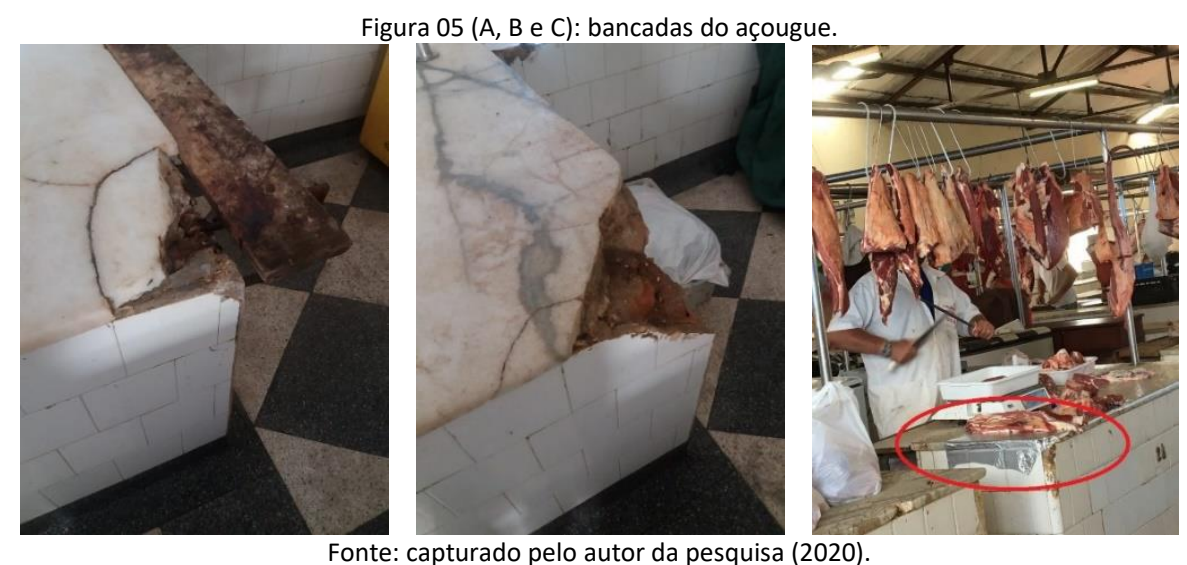

Ainda sobre as normas e leis regulamentadoras, à luz do artigo $39^{\circ}$ do decreto 38691 de 10/03/1997, foram notadas diversas irregularidades que podem gerar risco a saúde humana no açougue público estudado. Conforme os incisos expostos na fundamentação teórica deste artigo, é possível apontar alguns onde ocorre uma divergência entre a estrutura real do ambiente e o que está descrito na lei. Entre eles citamos a discordância entre o local estudado e os seguintes incisos: inciso terceiro, onde notamos que no ambiente não há iluminação artificial ou natural suficiente em cima das bancadas, por se tratar de um local onde é manuseado facas, deveria ser bem iluminado; o inciso sexto que específica a necessidade de forro, contudo no ambiente não há forro ou nenhuma estrutura construída de modo a evitar o acúmulo de sujeira e a contaminação; e o inciso nono que demanda que o ambiente esteja equipado com mesas revestidas de material impermeável. No inciso quarto e também no quinto as normas tratam a respeito de alguns revestimentos como o chão e paredes, é possível afirmar que no Açougue Público aqui falado, esses revestimentos se encontram degradados, com mofo e sem manutenção (Figura 06, A e B), este fator pode ocasionar acidentes e doenças tanto para os açougueiros, tanto para os clientes que frequentam aquele espaço. 

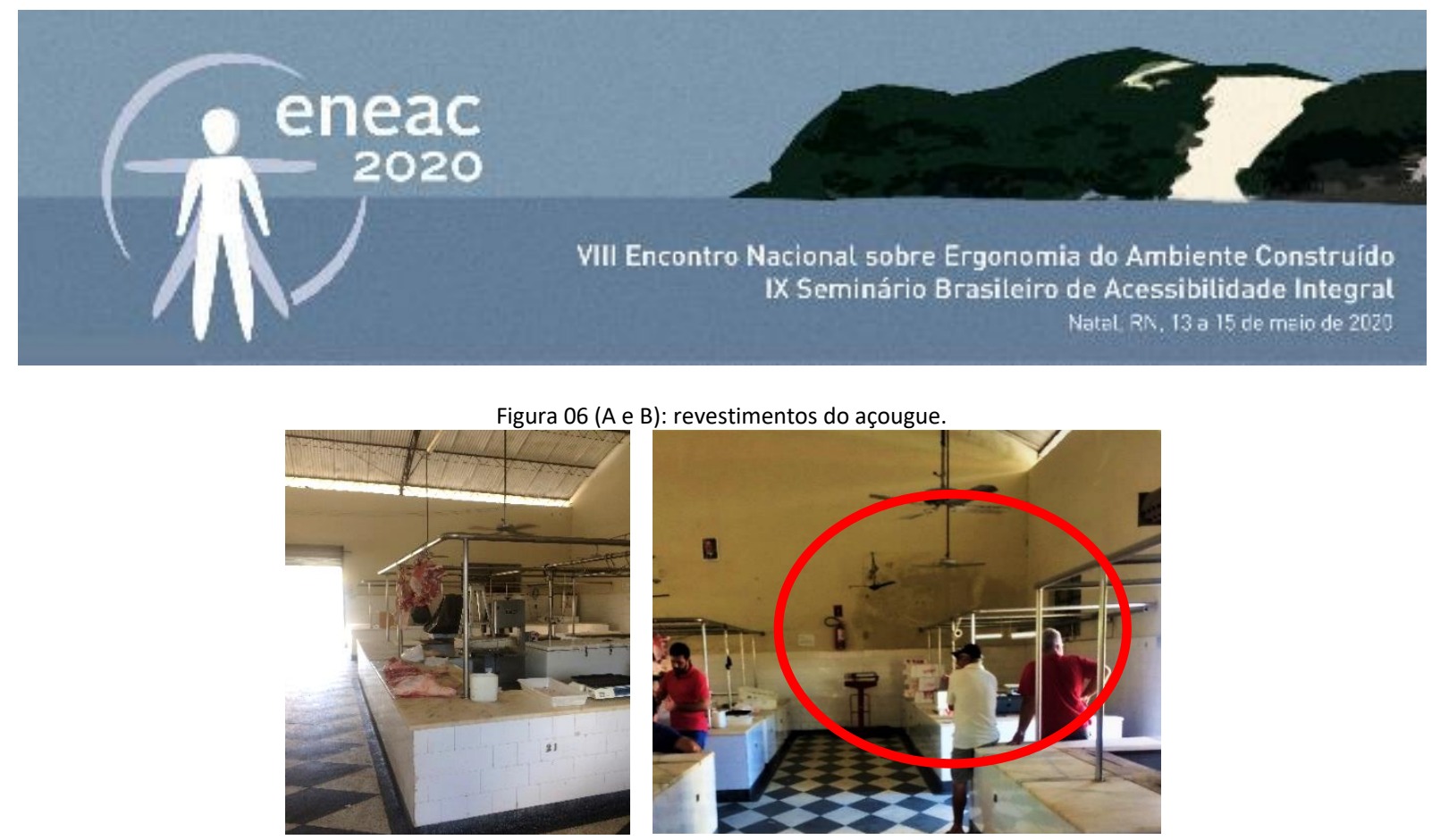

Fonte: capturado pelo autor da pesquisa (2020).

Sobretudo, o inciso sétimo do artigo $39^{\circ}$ do decreto 38691, o qual trata da necessidade do local de possuir dependências que se destinem também à recepção da matéria-prima e provavelmente dos produtos de origem animal, viu-se que, no açougue público analisado, as carnes chegam ao local apoiadas nas costas dos funcionários das transportadoras, os quais não usam vestuário ou equipamentos adequados (Figura 07, A e B). A entrega é feita a qualquer horário do dia e em vários dias da semana, inclusive em dias de maior movimento, causando transtornos nos usuários indiretos que estão no local. Salientamos que o transporte dessas peças de carne força os funcionários das empresas de entrega a assumirem posturas desconfortáveis e prejudiciais à saúde.

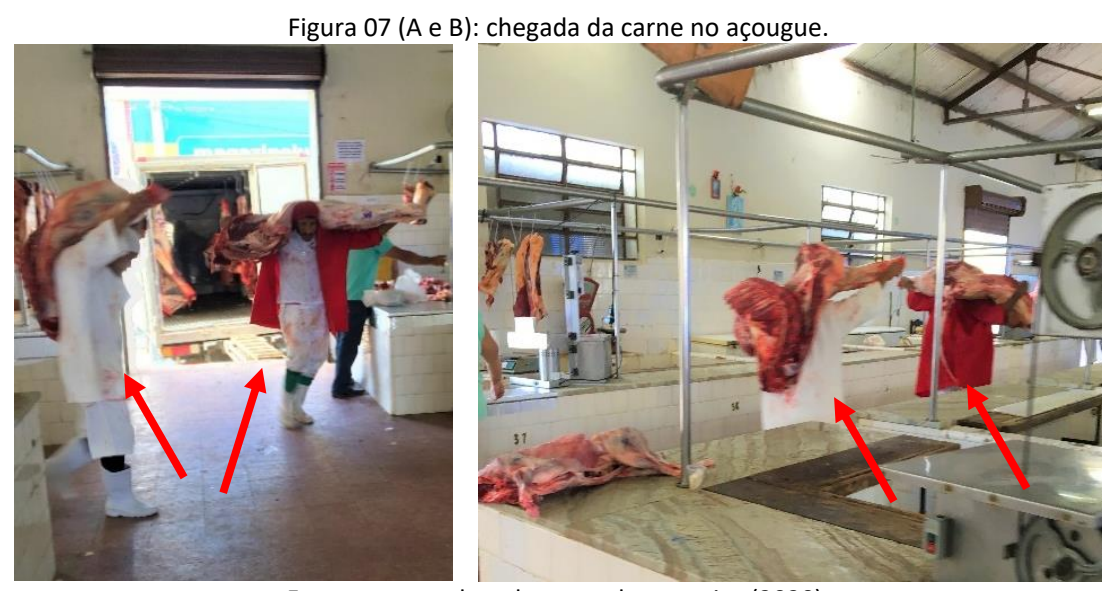

Fonte: capturado pelo autor da pesquisa (2020).

Também foi possível notar a falta de higienização e cuidado com as bancadas, qualquer pessoa pode tocar, colocar outros objetos e até mesmo sentar (Figura 08, A). 0 ambiente é totalmente aberto e não tem controle de entrada, isso inclui animais como cachorros, gatos, pássaros e diversos insetos (Figura 08, B). $O$ risco de acidentes, cortes, proliferação de germes e bactérias e até mesmo ataque de animais é possível nesse local. 

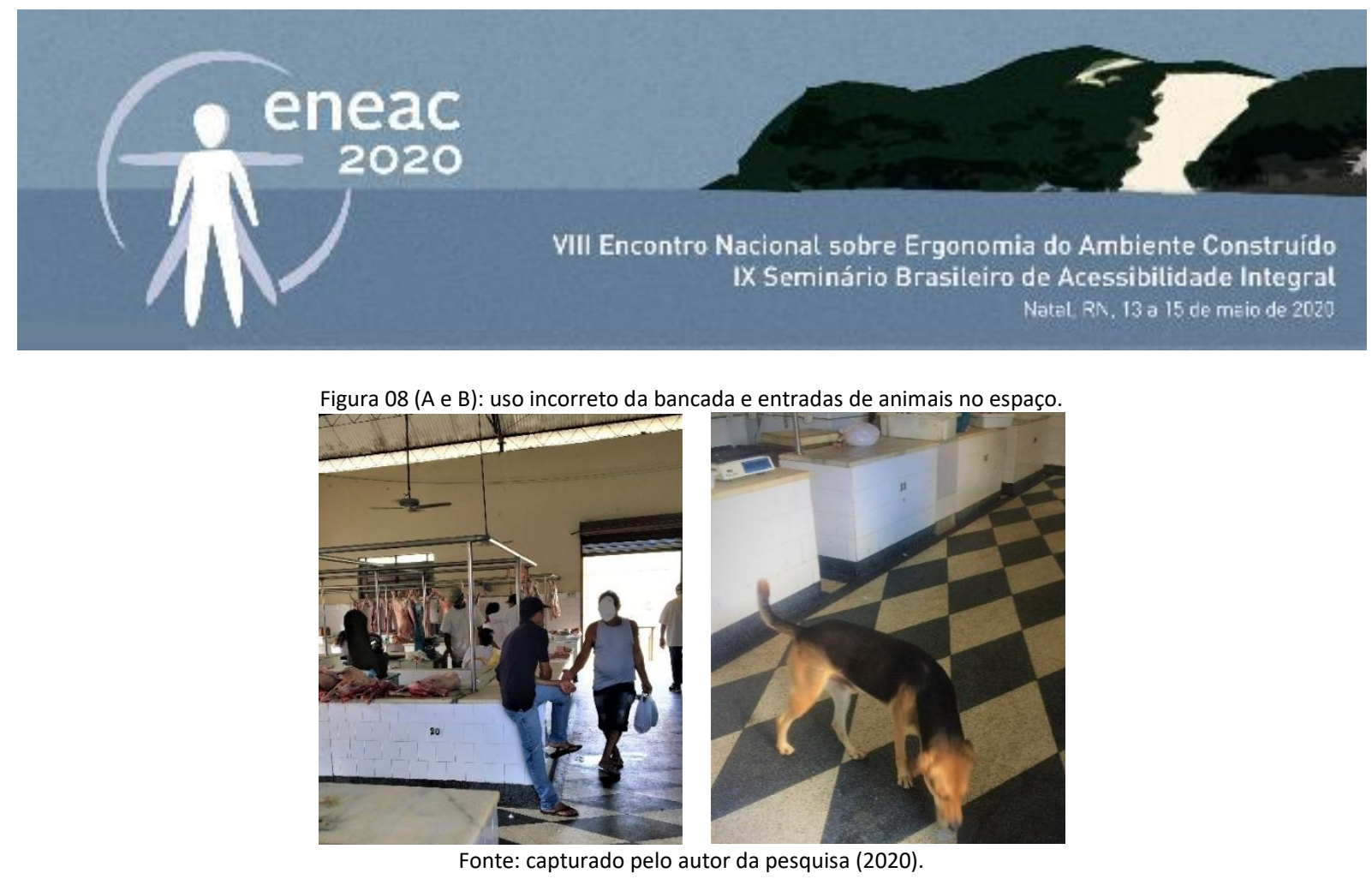

\section{Análise antropométrica do açougue}

Para dar continuidade ao projeto, foi vista a necessidade de realizar uma análise antropométrica do ambiente, para fins de comparação com as medidas de projeto recomendadas por Panero e Zelnik (2016). As medidas do açougue e seus objetos foram analisados e comparados com as medidas recomendadas por Panero e Zelnik (2013), contudo em seu livro Dimensionamento Humano Para Espaços Interiores não faz referência direta ao ambiente de um açougue, por isso alguns dados foram identificados do ambiente da cozinha e de demais espaço públicos.

A altura do balcão do açougue é 76 centímetros, isso força os açougueiros a assumirem uma posição de flexão do tronco, assim como uma flexão maior que 30 ㅇ do pescoço, podendo gerar desconforto e dores lombares. É possível notar a inadequação da altura quando os autores Panero e Zelnik (2016) recomendam uma altura entre 88,9 e 91,4 centímetros para zona de trabalho principal das bancadas de cozinha, o que pode se aplicar a bancadas de açougue, que por sua vez têm utilidades similares.

A bancada se encontra com uma profundidade de 37 centímetros, esta dimensão é padrão em todo o açougue, contudo, como foi mencionado anteriormente, alguns açougueiros colocaram tábuas de madeira para ampliar a área de trabalho, por isso algumas bancadas tem uma profundidade que varia entre 50 e 55 centímetros. Panero e Zelnik (2016) recomendam uma profundidade variável entre 61 e 66 centímetros para zona de trabalho principal das bancadas, o que sugere a inadequação das bancadas analisadas.

É importante informar que os corredores tanto horizontais não são utilizados apenas para circulação de clientes, uma vez que os módulos de cada açougueiro não tem espaço destinado a espera ou escolha do produto, quase sempre é possível ver uma pequena aglomeração de pessoas ao redor das bancadas aguardando sua vez de atendimento (Figura 09, A). Neste sentido, coube avaliar o espaço de circulação horizontal disponível, onde a dimensão individual recomendada é de 76,2 centímetros (PANERO e ZELNIK, 2016). Como em todos os corredores existe uma bancada de cada lado, é necessário ser oferecido um espaço adicional de 152,4 centímetros da área, o qual seria destinado para a espera de ambos os lados. Os autores Panero e Zelnik (2016) indicam a dimensão de 172,7 centímetros apenas para área de passagens e circulação de locais públicos, já o espaço do corredor do açougue analisado é de 215,0 centímetros (Figura 09, B). Tendo em vista a necessidade de espaço para a zona de espera seria, portanto, necessário oferecer um total de 325,1 centímetros, 110,1 


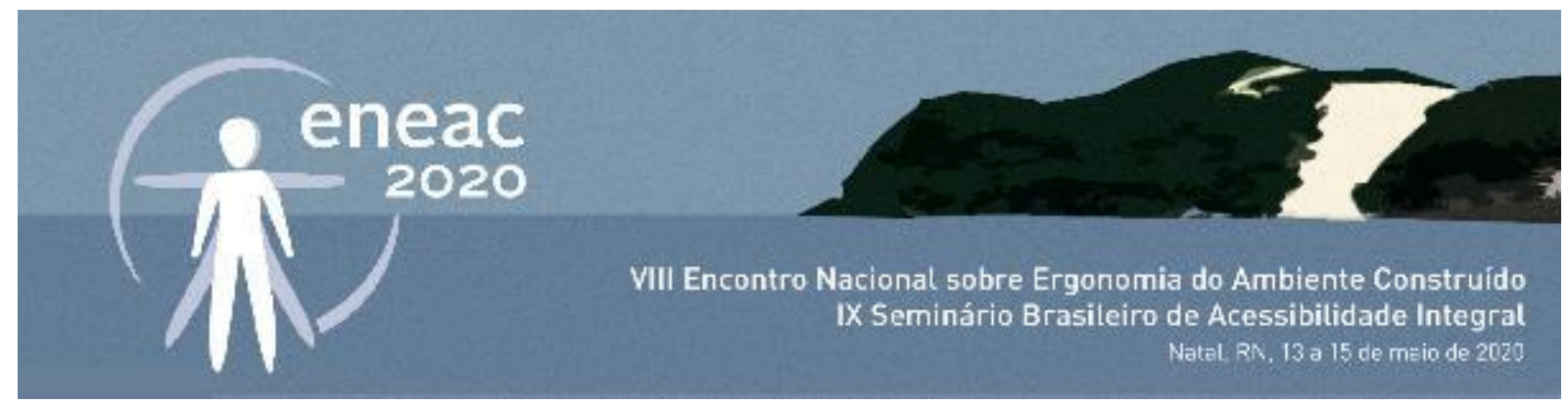

centímetros além do que é oferecido pelo estabelecimento. Considerando os espaços necessários, em ambos os lados, para espeça do atendimento, o açougue oferece apenas 62,6 centímetros para circulação, o que é ainda menor que o suficiente para uma pessoa apenas.

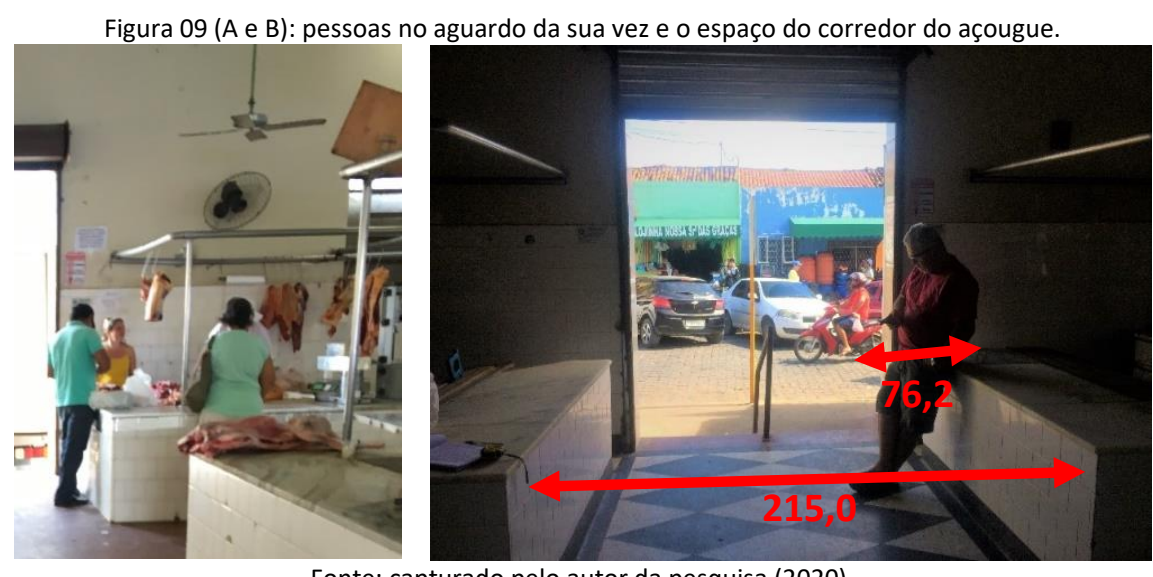

Fonte: capturado pelo autor da pesquisa (2020).

Também foi percebido o pequeno espaço para entrada dos açougueiros nos módulos, tem abertura que varia entre 34 centímetros até 70 centímetros (Figura 10), o que divergem com o recomendado por Panero e Zelnik (2016) que recomendam um espaço de $91,4 \mathrm{~cm}$ para tanto um cadeirante quanto uma pessoa sem deficiência conseguir transitar confortavelmente.

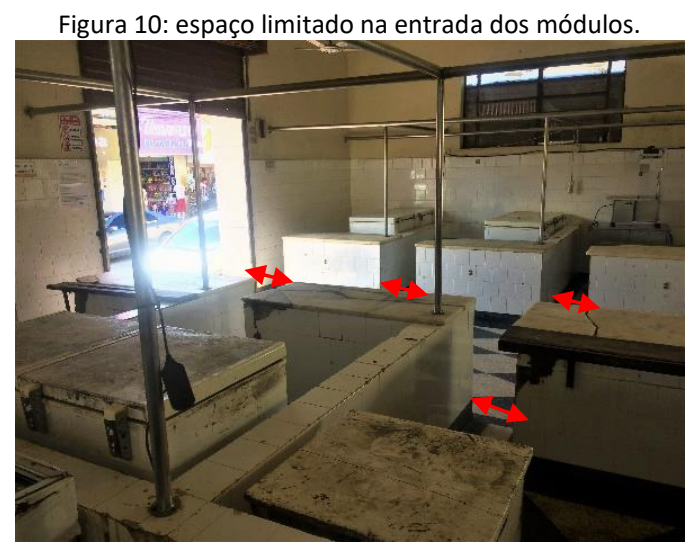

Fonte: capturado pelo autor da pesquisa (2020).

\section{Conforto Ambiental}

Durante esta fase, foram verificados em dois horários diferente os níveis de temperatura, ruído, ventilação e iluminação do local. Vale salientar que os dias de maior movimento são o sábado e o domingo, e a captação dos dados de conforto ambiental deste estudo foi realizada numa quintafeira, deste modo, os dados registrados como o de temperatura e ruído pode ser ainda mais elevados nos dias de sábado e domingo. foram utilizados aparelhos de conformidade obrigatória recentemente calibrados da marca UNI-T. Para verificar o índice de iluminação, foi utilizado o Luxímetro, que mede o índice de Lux no ambiente. Por sua vez, para verificar o índice de 


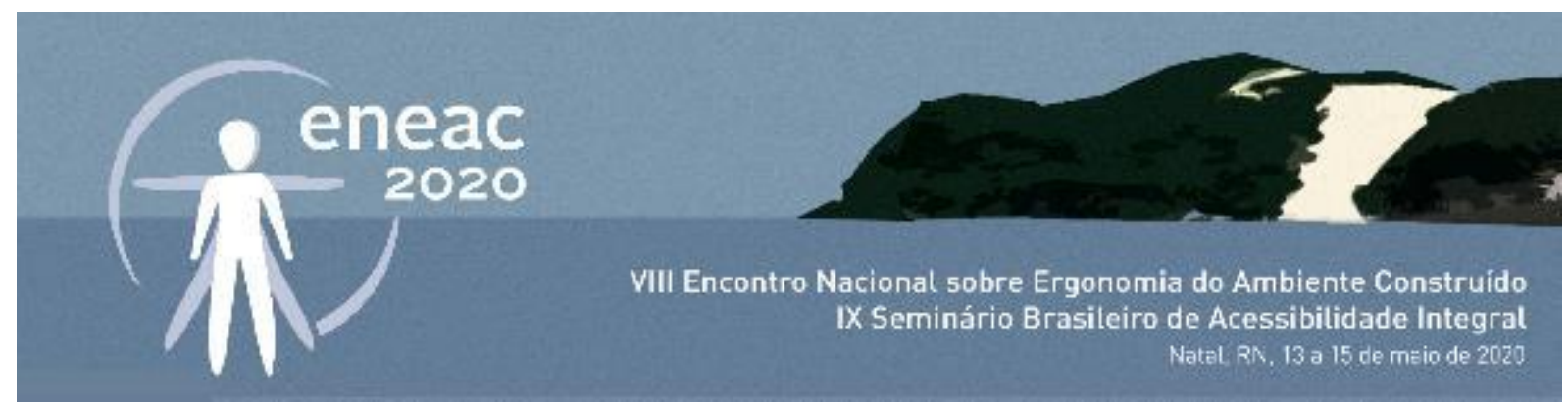

temperatura e velocidade do vento, foi utilizado o Termoanemômetro e, por fim, para analisar o índice de decibéis no ambiente foi utilizado o Decibelímetro. Dessa maneira, foi possível realizar comparativos entre as medições realizadas e as recomendações das Normas técnicas em busca de averiguar a adequação das medidas encontradas. A temperatura foi aferida às 9:30h e o ambiente possuía $27{ }^{\circ} \mathrm{C}$, e às $14: 30$ a temperatura subiu para $28^{\circ} \mathrm{C}$. Nos locais de trabalho onde são executadas atividades que exijam atenção constantes é recomendado pela NR 17 que a temperatura no ambiente esteja entre $20 \circ \mathrm{C}$ e $23 \circ \mathrm{C}$, dessa maneira o ambiente não se enquadra no que estabelece as normas regulamentadoras. Ressaltando ainda que as carnes ficam exposta a essa temperatura também, por todo o dia.

Para parâmetros de ruído, foi observado que os níveis registrados não geram grandes incômodos, ao menos nos dias de baixo movimento, foram detectados os resultados a seguir em decibéis: às 9:35h o mínimo de $57 \mathrm{~dB}$ e máximo de $60 \mathrm{~dB}$, as $14: 35$ o mínimo de $75 \mathrm{~dB}$ e o máximo de $79 \mathrm{~dB}$. De acordo com a NBR 10151 que detalha que para as atividades em áreas mistas com convocações comerciais e administrativa, o nível de ruído aceitável para efeito de conforto será de até $60 \mathrm{~dB}$. É possível afirmar então, que pôr ambiente se tratar de uma área de comercialização pública o nível de ruído se encontra aceitável.

Os parâmetros da iluminação verificados durante o dia de avaliação mostraram pouca diferença entre os horários avaliados, pela manhã às 9:38h o índice estava 222 Lux em quase todo o ambiente, e só chegava a variar entre 260 Lux quando se aproximava das portas de acesso do ambiente. Mais tarde às 14:37 permaneceu em 230 Lux na maior parte do ambiente, e ao se aproximar da porta de entrada, variou entre 285 Lux. É importante afirmar que o índice de iluminação em cima das bancadas, onde é necessário a melhor visualização, já que nessa parte do ambiente são utilizados utensílios como facas, moedores, ganchos, e outros materiais afiados, foi notado que o indicie de iluminação estava 195 Lux. Nota-se que os índices de iluminância encontram-se inadequados por estarem baixos, tanto no ambiente real de uso como os balcões de corte, como no restante do ambiente. Pelas normas da ABNT NBR 5413 que sugere níveis de iluminação entre 300 Lux à 500 Lux.

A aeração foi verificada também em dois horários distintos, às 9:40h e foi constatada uma ventilação entre $0,00 \mathrm{~m} / \mathrm{s}$ e $3,00 \mathrm{~m} / \mathrm{s}$ variando da proximidade com as portas de acessos ao local, e às 14:40hrs a ventilação não foi fortemente alterada permanecendo entre $0,00 \mathrm{~m} / \mathrm{s}$ e $2,50 \mathrm{~m} / \mathrm{s}$, ainda de acordo com a NR 17 que sugere que a velocidade do ar não seja superior a $0,75 \mathrm{~m} / \mathrm{s}$, a aeração do ambiente se encontra inadequada.

\subsection{ADAPTAÇÃO ÀS NECESSIDADES DOS USUÁRIOS}

Após a realização da análise da tarefa, foi possível identificar as inadequações que impedem o ambiente de atender as necessidades específicas dos usuários desse estudo de caso. Notou-se ainda, no decorrer da realização das atividades, algumas das dificuldades que os usuários indiretos também enfrentam para fazer uso desse ambiente. Foi possível perceber que muitos dos riscos que açougue o apresenta não estão visíveis a todos, como a proliferação de bactérias na própria carne que não está refrigerada, a bancada que não é do material adequado e pode também está infectada com germes, assim como revestimento mofado, quebrado, desgastado e sem manutenção. O local de corte da carne também deveria ser esterilizado periodicamente, ou neste caso, a cada corte de carne. 


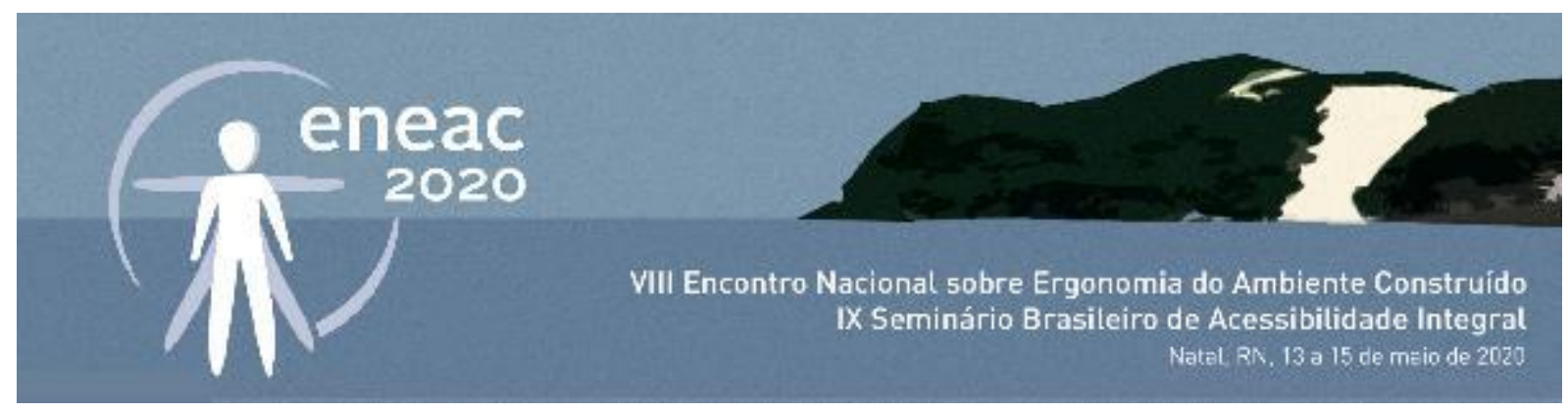

As posturas que as bancadas forçam os açougueiros assumir prejudica a saúde tanto a curto, como a longo prazo desses usuários. Dores nos ombros, costas e pescoço já foram documentadas, essas fadigas e sobrecargas osteomusculares podem ocasionar doenças serias como hérnias, bursite, tendinopatia e outras lesões. Também foi vista a falta de preparo que tem os entregadores que carregam peças gigantes de carne nas costas andando por dentro do açougue no horário de funcionamento. Tudo isso é somado a falta de trajes específicos para manuseio de produtos alimentícios e de utensílios cortantes como é o caso dos moedores de carne, cortadores elétricos e as facas. $\mathrm{O}$ ambiente também apresenta uma temperatura bem mais alta do que a ABNT recomenda, isso gera mais desconforto já que além de ter um local quente o mal cheiro da carne exposta aumenta e a quantidades de moscas e insetos no ambiente também. Outro problema detectado foi a falta de supervisão, os animais entram e saem de lá normalmente, proliferando mais uma vez o risco de germes e bactérias no ambiente.

Isto posto, foi realizada a seguinte Lista de Recomendações Ergonômicas:

Quadro 1: Recomendações ergonômicas para o açougue analisado.

\begin{tabular}{|c|c|}
\hline 1 & $\begin{array}{l}\text { Organizar o leiaute do ambiente, mesmo que fosse necessário alterar sua estrutura original, evitando assim gerar } \\
\text { desconforto e possibilitar a entrada nos módulos pelos diversos tipos de usuários que possam vir usar esse espaço; }\end{array}$ \\
\hline 2 & $\begin{array}{l}\text { Ao invés de expor as carnes em um varal, colocar balcões vitrines refrigeradas, que expõem as carnes, mas as } \\
\text { mantem refrigeradas e conservadas, evitando que elas apodreçam; }\end{array}$ \\
\hline 3 & $\begin{array}{l}\text { Que haja uma supervisão controladora em todas as portas de acesso do ambiente, dessa maneira os animais não } \\
\text { iram adentar no açougue; }\end{array}$ \\
\hline 4 & $\begin{array}{l}\text { Que as portas de enrolar sejam trocadas por portas de vidro, dessa maneira elas poderiam ser fechadas e não iria } \\
\text { perder a incidência de luz natural e da visão do exterior e a aeração do ambiente iria ser controlada; }\end{array}$ \\
\hline 5 & $\begin{array}{l}\text { Que todo o ambiente fosse climatizado, para o excesso de calor deixar de gerar desconforto tanto para os usuários } \\
\text { diretos como os usuários indiretos; }\end{array}$ \\
\hline 6 & $\begin{array}{l}\text { Que seja colocado um forro adequado no ambiente, de laje ou de gesso, mas que impedisse a entrada de pássaros } \\
\text { e mais insetos no local; }\end{array}$ \\
\hline 7 & É necessária a colocação de lâmpada em cima de cada bancada, já que nesse lugar se usa utensilio cortantes; \\
\hline 8 & $\begin{array}{l}\text { Todas as bancadas devem ser aumentadas para altura que os autores Panero e Zelnik (2013) recomendam, assim } \\
\text { as lesões que as atividades exercidas pelos açougueiros causam, sejam minimizadas. }\end{array}$ \\
\hline 9 & $\begin{array}{l}\text { É importante que o munícipio ou o estado disponibilizem cursos de açougueiros, para que esses trabalhadores } \\
\text { tenham noção de como cuidar do seu ambiente de trabalho e os cuidados que devem ter na manipulação das } \\
\text { carnes; }\end{array}$ \\
\hline 10 & $\begin{array}{l}\text { Também é preciso o uso de vestimentas adequadas, para evitar o risco de } \\
\text { cortes e contaminações; }\end{array}$ \\
\hline 11 & $\begin{array}{l}\text { Os revestimentos do ambiente também precisam de uma reparação, os que estão rachados e quebrado precisam } \\
\text { ser trocados, a origem do mofo precisa ser encontrada e resolvida; }\end{array}$ \\
\hline 12 & $\begin{array}{l}\text { Todo o ambiente precisa estar de acordo as normas da vigilância sanitária e da } \\
\text { ANVISA; }\end{array}$ \\
\hline
\end{tabular}

Fonte: Elaborado pelos autores para a pesquisa (2020).

\section{CONCLUSÃO}

Ao levar em consideração e alinhar as normas, diretrizes e regulamentos sobre estabelecimentos que fazem uso de produtos alimentícios de origem animal, aos conhecimentos em Ergonomia do Ambiente Construído, foi possível, apontar os prejuízos ergonômicos e os riscos que os usuários estão expostos ao trabalhar e frequentar açougues que não seguem o regulamento. Projetar ambientes adequados exige uma tomada de consciência dos comportamentos dos usuários, levando em consideração que todas as variáveis humanas influenciam do início ao fim no processo do projeto. 0 


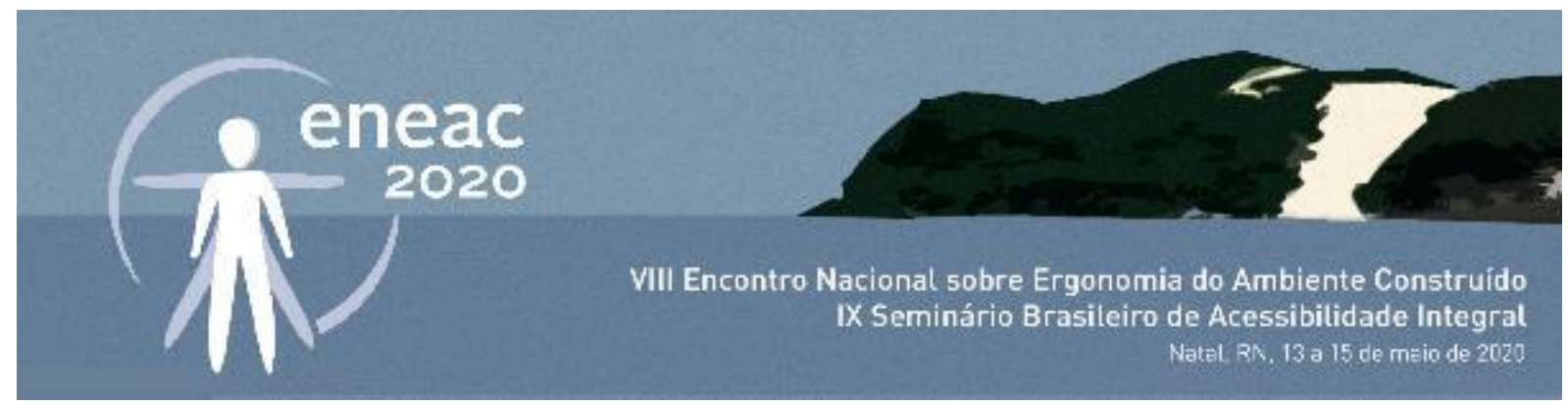

estudo sugere diversas inadequações relacionadas à utilização do ambiente, tanto pelos açougueiros que, em maioria, não tem conhecimento do prejuízo que aquele local pode trazem a si mesmos, como a falta de informação sobre os cuidados com a carne, que pode acarretar diversas consequências tanto para o açougueiro, como para o cliente. Ao se observar atentamente as dificuldades e consequências, é possível afirmar que, caso não sejam solucionadas através de uma intervenção ergonômica focada no conforto e bem-estar de seus usuários diretos e indiretos, podem vir a causar uma série de fatores complexos e negativos. Portanto, com base nos resultados da aplicação metodológica, que apontou os diversos problemas no ambiente, ficou evidente a necessidade de adaptações, sendo, então, estabelecida uma lista de recomendações ergonômicas a serem consideradas para a adequação do açougue público.

A Metodologia para Projetos de Construção Centrados no Usuário, proposta por Attaianese e Duca (2012) se mostrou objetiva, no entanto (até a realização do presente estudo), não se encontrou uma publicação sobre a aplicação detalhada das etapas propostas na estrutura de procedimentos. Durante a investigação, foi percebido que a metodologia proposta pelas autoras não especifica procedimentos relacionados a antropometria e ao conforto ambiental, conteúdos esses que se fazem necessários para a completude de um estudo ergonômico. O fato exigiu uma maior cautela e experiência dos pesquisadores, onde, para complementar o estudo, foi acrescentada a Análise Antropométrica e a de Conforto Ambiental, dessa forma, foi possível realizar medições e comparativos com normas em vigor.

\section{REFERÊNCIAS}

ATTAIANESE, E.; DUCA, G. Human factors and ergonomic principles in building design for life and work activities: an applied methodology. Theoretical Issues in Ergonomics Science. Vol. 13, No. 2, March-April 2012, 187-202.

CYMBALUK, Fernando. Carne estragada pode causar infecção; a carne boa já tem coliformes fecais. UOL. São Paulo, 2017. Disponível em: https://noticias.uol.com.br/saude/ultimas-noticias/redacao/2017/03/17/carne-boa-tem-coliformes-fecais-eresiste-so-duas-horas-sem-refrigeracao.htm. Acesso em: 04 fev. 2020.

MELZER, A. C. S. Fatores de risco físicos e organizacionais associados a distúrbios osteomusculares relacionados ao trabalho na indústria têxtil. Fisioterapia e Pesquisa. São Paulo, v. 15, n. 1, 2008. Disponível em: <

http://www.scielo.br/scielo.php?pid=S1809-29502008000100004\&script=sci_arttext >. Acesso em: 12 dez. 2019.

MINISTÉRIO DO TRABALHO E EMPREGO. Portal do trabalho e emprego. CBO - Classificação Brasileira de Ocupações, 2013. Disponível em < http://www.mtecbo.gov.br/ >. Acesso em: 11 jan. 2020.

OCDE. Production, consumption and exports of poultry meat in Brazil. Dans overview and special chapter, Éditions OCDE. Paris, 2015

PANERO, J.; ZELNIK, M. Dimensionamento humano para espaços interiores. Gustavo Gili, 2016.

SARMENTO, Thaisa F. C. S.; VILLAROUCO, Vilma. Desenvolvimento de um modelo conceitual de ambiente de aprendizagem. In: São Paulo: Blucher, 2018. p. 56-62.

TONDO, Eduardo. "O consumidor não percebe..." In: CYMBALUK, Fernando. Carne estragada pode causar infecção; a carne boa já tem coliformes fecais. UOL. São Paulo, 2017. Disponível em: https://noticias.uol.com.br/saude/ultimasnoticias/redacao/2017/03/17/carne-boa-tem-coliformes-fecais-e-resiste-so-duas-horas-sem-refrigeracao.htm. Acesso em: 04 fev. 2020.

VASCONCELLOS, M. C.; PIGNATTI, M. G.; PIGNATI, W. A. Emprego e acidentes de trabalho na indústria frigorífica em áreas de expansão do agronegócio, Mato Grosso, Brasil. Saúde e Sociedade. São Paulo, v. 18, n.4, Dez. 2009. Disponível em <http://www.scielo.br/scielo.php?script=sci_arttext\&pid=S0104-12902009000400010\&lng=en\&nrm=iso >. Acesso em: 03 Dez. 2019. 